\title{
Fuzzy Tahani Method in the Recommendation System for Selecting Mountain Tourism Destinations in West Java
}

\author{
Agung Wahana ${ }^{1}$, Esa Firmansyah ${ }^{2}$, Hasby Ifkar Al Rosyid ${ }^{3}$, Rifqi Syamsul Fuadi ${ }^{4}$, Dian \\ Sa'adillah Maylawati ${ }^{5}$ \\ \{wahana.agung@uinsgd.ac.id ${ }^{1}$, esa@stmik-sumedang.ac.id ${ }^{2}$, hasbyifkaralrosyid@gmail.com³ \\ rifqi@uinsgd.ac.id ${ }^{4}$,diansm@uinsgd.ac.id ${ }^{5}$ \} \\ Department of Informatics, UIN Sunan Gunung Djati Bandung, Indonesia ${ }^{1,2,3,4,5}$ \\ Sekolah Tinggi Manajemen Informatika dan Komputer Sumedang ${ }^{3}$ \\ Faculty of Information and Technology, Universiti Teknikal Malaysia Melaka, Malaysia ${ }^{5}$
}

\begin{abstract}
West Java is a province that is famous for its diversity of tourism objects, especially natural mountain attractions. West Java itself has a variety of mountain attractions ranging from volcanoes, mountain craters, and extensive mountain savanna. This tour is visited by many local and foreign tourists. The problem faced by tourism is the lack of information about tourist locations, facilities and entry rates for tourism objects. The method used in this study is Fuzzy Tahani which will provide recommendations on mountain tourism objects in West Java. The purpose of this study is to provide recommendations to tourists who will visit mountain tourism in West Java according to the criteria desired by tourists. Test data used as many as 20 with an accuracy rate of $85 \%$.
\end{abstract}

Keyword: Mountain Tourism, Lack of information, Fuzzy Tahani, Recommended Mountain Tourism.

\section{Introduction}

The tourism sector in Indonesia is currently considered to be an effective role in increasing foreign exchange. Indonesia is one of the countries that has many exotic mountains, the natural wealth of mountains in Indonesia, especially in West Java, which greatly encourages the development of mountainous nature tourism as well as mountain climbing. From the data obtained there are 364 mountains spread over West Java and around 21 mountain attractions that have been managed by the West Java Tourism Office[1].

The number of visitors in natural attractions, especially mountain tourism, has recently increased significantly thanks to the influence of one of the communication technologies, namely social media such as Facebook, Twitter and Instagram with the help of information technology about mountain tourism objects that can be better known by many people[2].

Before someone goes on a tour they first look for all the information as much as possible about the area or location of mountain tourism that will be targeted so they can prepare time, budget, and so on because information on a tourist object is needed to support in determining the destination of tourism. 


\section{Methodology}

The software development method used to build the system is a prototype model. According to Roger S. Pressman, the prototype approach is very suitable for systems or devices that are built following user requirements[3].

Stages of Software Development Process with Prototype:

a. Communication, developers and clients meet and determine general objectives, desired needs and description of the parts that will be needed.

b. Quick Plan, the design is done quickly and represents all known aspects of the software, and this design is the basis for making prototypes.

c. Modeling Quick Design, focuses on the representation of software aspects that can be seen by the user. Modeling quick design tends to make prototypes. The modeling method used in making this application is using UML or Unified Modeling Language.

d. Construction of Prototype, build a framework or design prototype of software that will be built.

e. Deployment Delivery \& Feedback, the prototype that has been made by the developer will be distributed to the user, to be evaluated, then the user will provide feedback that will be used to revise the software requirements that will be built. Repetition of this process continues until all needs are met. [5]

\section{Result and Discussion}

a. Business modeling

Public tourists can find out information about natural attractions, especially mountains, by finding information from several media. including newspapers, brochures, internet / social media, these three media are commonly used by tourists in seeking information.

b. Modeling system requirements

In building a system, system analysis needs to be needed so that the system that is built out of the design that has been made System Requirement Modeling consists of functional requirements and a proposed system. The table below is a list of functional requirements for the recommended system for selecting mountain attractions.

c. Fuzzy tahani algorithm

Fuzzy tahani is one of the branches of fuzzy logic, which is one of the fuzzy methods that uses a standard database. Keep describing a method of fuzzy query processing, based on language manipulation known as the SQL (Structured Query Language), so that the fuzzy tahani model very appropriate to use in the process of finding the right and accurate data.[4].

Fuzzy database system is one fuzzy method that uses a standard database. In a standard database, data is classified based on how the data is viewed by the user. Therefore, in the standard database the data displayed will come out like the data that has been stored. But in reality, someone sometimes needs information from ambiguous data. Whereas in the standard database system the data displayed cannot display ambiguous data. Therefore, if this happens, it is better to use a fuzzy database system [4][5]. 


\section{Stages of Fuzzy Tahani}

a. Determining Membership Criteria and Process

Criteria for mountain tourism objects (variables) are used as a basis for determining mountain tourism recommendations using the tahini fuzzy model algorithm.

- $\quad$ Price (Cheap, Medium, Expensive)

- Facilities (Small, Medium, Complete)

- $\quad$ Operating Hours (Fast, Medium, Long)

Table 1. Tourist Site

\begin{tabular}{lccc}
\hline \multicolumn{1}{c}{ Tourism site } & Price & Facilities & Operating Hours \\
\hline Ciremai Mountain & Rp. 50.000 & 5 & $07.00-20.00$ \\
Puncak Mega & Rp. 15.000 & 8 & $24 \mathrm{Hr}$ \\
Puncak Darma & Rp. 17.000 & 6 & $07.00-17.00$ \\
\hline
\end{tabular}

b. Fuzzyfication process

- Price Curve

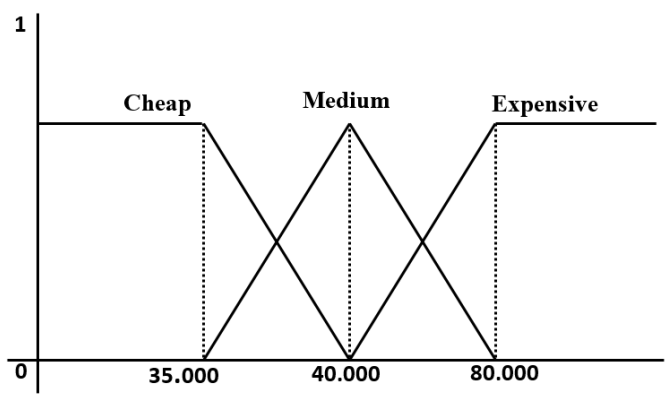

Fig. 1. Price Membership function

$$
\begin{aligned}
& \mu \text { PriceCheap }(\mathrm{x})=\left\{\begin{array}{lc}
1 ; & x \leq 35.000 \\
\frac{40.000-x}{40.000-35.000} ; & 35.000 \leq x \leq 40.000 \\
0 ; & x \geq 40.000
\end{array}\right. \\
& \mu \text { PriceMedium }(\mathrm{x})=\left\{\begin{array}{lc}
0 ; 35.000 \geq \text { atau } x \geq 80.000 \\
\frac{x-35.000}{40.000-35.000} ; & 35.000 \leq x \leq 40.000 \\
\frac{80.000-x}{80.000-40.000} ; & 40.000 \leq x \leq 80.000
\end{array}\right.
\end{aligned}
$$


$\mu$ PriceExpensive $(\mathrm{x})=\left\{\begin{array}{cl}0 ; & x \leq 40.000 \\ \frac{x-40.000}{80.000-40.000} ; & 40.000 \leq x \leq 80.000 \\ 1 ; & x \geq 80.000\end{array}\right.$

Table 2. Degree of Price Membership

\begin{tabular}{cccc}
\hline \multirow{2}{*}{ Set Name } & \multicolumn{3}{c}{ Price } \\
\cline { 2 - 4 } & Cheap & Medium & Expensive \\
\hline Ciremai Mountain & 0 & $\mathbf{0 . 7 5}$ & 0.25 \\
Puncak Mega & $\mathbf{1}$ & 0 & 0 \\
Puncak Darma & $\mathbf{1}$ & 0 & 0 \\
\hline
\end{tabular}

- Facilities Curve

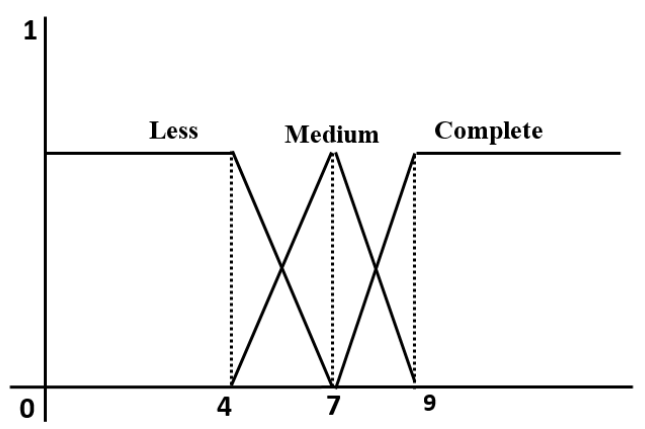

Fig. 2. Facilities Membership function

$$
\begin{aligned}
& \mu \mathrm{facilitiesLess}(\mathrm{x})=\left\{\begin{array}{lr}
1 ; & x \leq 4 \\
\frac{7-x}{7-4} ; & 4 \leq x \leq 7 \\
0 ; & x \geq 7
\end{array}\right. \\
& \mu \text { aacilitiesMedium }(\mathrm{x})=\left\{\begin{array}{lr}
0 ; & 4 \geq \text { atau } x \geq 9 \\
\frac{x-4}{7-4} ; & 4 \leq x \leq 7 \\
\frac{9-x}{9-7} ; & 7 \leq x \leq 9
\end{array}\right. \\
& \text { pasclitiesComplete }(\mathrm{x})=\left\{\begin{array}{lr}
0 ; & x \leq 7 \\
\frac{x-7}{9-7} ; & 7 \leq x \leq 9 \\
1 ; & x \geq 9
\end{array}\right.
\end{aligned}
$$


Table 3. Degree of Facilities Membership

\begin{tabular}{cccc}
\hline Set Name & \multicolumn{3}{c}{ Facilities } \\
& Less & Medium & Complete \\
\hline Ciremai Mountain & $\mathbf{0 . 6 6}$ & 0.33 & 0 \\
Puncak Mega & 0 & $\mathbf{0 . 5}$ & 0.5 \\
Puncak Darma & 0.33 & $\mathbf{0 . 6 6}$ & 0 \\
\hline
\end{tabular}

- Operating Hour Curve

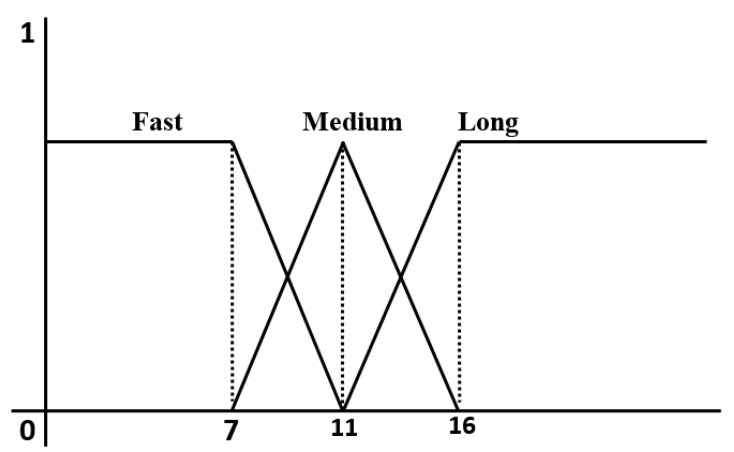

Fig. 3. Operating Hour Membership function

$$
\begin{aligned}
& \mu \text { OprHourFast }(\mathrm{x}) \quad=\left\{\begin{array}{cc}
1 ; & x \leq 7 \\
\frac{7-x}{11-7} ; & 7 \leq x \leq 11 \\
0 ; & x \geq 11
\end{array}\right. \\
& \mu \mathrm{OjprHourMedium}(\mathrm{x})=\left\{\begin{array}{lr}
0 ; & 7 \geq \text { atau } x \geq 16 \\
\frac{x-7}{11-7} ; & 7 \leq x \leq 11 \\
\frac{16-x}{16-11} ; & 11 \leq x \leq 16
\end{array}\right. \\
& \mu \text { OprHourLong }(\mathrm{x}) \quad=\left\{\begin{array}{lr}
0 ; & x \leq 11 \\
\frac{x-11}{16-11} ; & 11 \leq x \leq 16 \\
1 ; & x \geq 16
\end{array}\right.
\end{aligned}
$$


Table 4. Degree of Facilities Membership

\begin{tabular}{cccc}
\hline Set Name & \multicolumn{3}{c}{ Operating Hour } \\
& Fast & Medium & Long \\
\hline Ciremai Mountain & 0 & $\mathbf{0 . 6}$ & 0.4 \\
Puncak Mega & 0 & 0 & $\mathbf{1}$ \\
Puncak Darma & 0.25 & $\mathbf{0 . 7 5}$ & 0 \\
\hline
\end{tabular}

c. Query Fuzzyfication

Query fuzzyication process is a conventional DBMS query that is applied to the basic system of fuzzy query logic, this process is also carried out when trying to do a vague data search following is an example used.

INPUT:

Price="Cheap"

Facilites="Medium"

OperatingHours="Medium"

"SELECT * FROM [mountain] WHERE Price='Cheap' AND Facilities='Medium' AND OperatingHours='Medium",

d. Zadeh Basic Operation / Making Rules

The zadeh basic operation is used to combine and modify sets and produce fire strength or $\alpha$-predicate values and is divided into two parts:

- AND operator

The result of the AND operator is the smallest membership degree data:

$\mathrm{Fc}(\mathrm{X}) \quad=\min (\mathrm{Fa}(\mathrm{X}), \mathrm{fb}(\mathrm{X}))$

$\mathrm{Fc} \quad=$ searched value

$\mathrm{Fa}, \mathrm{Fb}=$ Degree of membership of each set

- OR operator

The result of the OR operator is the smallest membership degree data:

$\mathrm{Fc}(\mathrm{X}) \quad=\max (\mathrm{Fa}(\mathrm{X}), \mathrm{fb}(\mathrm{X}))$

$\mathrm{Fc} \quad=$ searched value

$\mathrm{Fa}, \mathrm{Fb}=$ Degree of membership of each set

$\operatorname{Fc}(\mathrm{X})=\max ($ DkPriceCheap, DkFacilitiesMedium)

$=\max (1,0.66)=1$

$\mathrm{Fc}(\mathrm{X}) \quad=\max (($ DkPriceCheap, DkFacilitiesMedium $)$, DkOprHourMedium $)$

$=\max (1,0.75)=1$

Table 5. Recommendation

\begin{tabular}{cccc}
\hline \multirow{2}{*}{ Set Name } & \multicolumn{3}{c}{ Degree of Membership } \\
& Price(Cheap) & Facilities(Medium) & OprHour(Medium) \\
\hline Puncak Mega & 1 & 0.66 & 0.75 \\
\hline
\end{tabular}




\section{Conclusion}

a. The Fuzzy Tahani method is able to provide recommendations for mountain tourism objects according to the criteria chosen by the user.

b. Test data used as many as 20 with an accuracy rate of $85 \%$.

\section{Acknowledgments}

We would like to give acknowledgement for the Faculty of Science and Technology, the Informatics Engineering Department and the Center for Research and Community Service at UIN Sunan Gunung Djati Bandung.

\section{References}

[1] Dinas Pariwisata dan Kebudayaan Jawa Barat, "Wisata Pegunungan Jawa Barat." [Online]. Available: http://www.disparbud.jabarprov.go.id. [Accessed: 10-May-2018].

[2] W. D. N. Kurniawati, "Pemanfaatan Instagram Oleh Komunitas Wisata Grobogan," Ilmu Komun. Univ. Muhammadiyah Surakarta, vol. 8, no. 2, pp. 127-143, 2016.

[3] D. Purnomo, "Model Prototyping Pada Pengembangan Sistem Informasi," JIMP - J. Inform. Merdeka Pasuruan, vol. 2, no. 2, pp. 54-61, 2017.

[4] A. Nurlayli, U. Pujianto, and F. Alqodri, "Penerapan Fuzzy Model Tahani Untuk Rekomendasi Lokasi Prakerin (Studi Kasus: Smkn 12 Malang)," Semin. Nas. Sist. Inf. Indones., no. November, pp. 501-508, 2015.

[5] Y. A. Gerhana, D. S. Maylawati, and G. M. Syukur, "Fuzzy Tahani Algorithm and REST Web Service for Tourist Destination Recommendation," 2018 6th Int. Conf. Cyber IT Serv. Manag. CITSM 2018, no. Citsm, 2019. 